\title{
Dampak Perkembangan Perumahan Terhadap Masyarakat di Sekitar Perumahan Kecamatan Baruga, Kota Kendari
}

\author{
*Adhitya Pratama, Sany Roychansyah, Yori Hergawati \\ Departemen Arsitektur dan Perencanaan, Magister Perencanaan Wilayah Dan Kota, Universitas Gajah Mada \\ *adhityaapratamaa@gmail.com
}

\section{INFO ARTIKEL}

Riwayat Artikel:

Diterima: 16-01-2020

Disetujui: 19-01-2020

\section{Kata Kunci:}

Perkembangan Perumahan

Masyarakat

Dampak Sosial

Dampak Ekonomi

Dampak Lingkungan

\begin{abstract}
ABSTRAK
Abstrak: Meningkatnya kebutuhan akan tempat tinggal dan terbatasnya lahan pusat kota menggeser pembangunan perumahan ke pinggiran kota. Wilayah pinggiran kota Kendari yakni Kecamatan Baruga, mengalami perkembangan perumahan yang begitu signifikan dan sporadis. Perkembangan perumahan memicu dampak dari segi sosial, ekonomi, dan lingkungan terhadap masyarakat lokal di sekitar perumahan yang sudah bermukim sebelum adanya perumahan. Penelitian bertujuan untuk mengambarkan proses perkembangan perumahan pada Kecamatan Baruga, sekaligus mengkaji dampak perkembangan perumahan tersebut terhadap masyarakat di sekitar perumahan. Metode yang digunakan dalam penelitian ini menggunakan pendekatan penelitian campuran ( $m i x$ method) yaitu penelitian yang menggambungkan antara pedekatan kualitatif dan kuantitatif. Temuan penelitian ini adalah perkembangan perumahan pada Kecamatan Baruga dari aspek ekonomi dan lingkungan tidak memberikan dampak positif terhadap masyarakat di sekitar perumahan, namun dalam aspek sosial perkembangan perumahan berdampak positif terhadap masyarakat di sekitar perumahan. Dari sebelas indikator yang diteliti terkait dampak perkembangan perumahan terhadap kondisi sosial, ekonomi dan lingkungan masyarakat sekitar perumahan, hanya terdapat empat indikator yang berdampak positif terhadap masyarakat sekitar perumahan, yakni peningkatan kegiatan sosial, peningkatan hubungan sosial, peningkatan kualitas hidup sosial, peningkatan ketersediaan lampu jalan dan peningkatan pelayanan persampahan. Sedangkan enam indikator lainnya tidak berdampak signifikan lebih baik terhadap masyarakat sekitar perumahan yakni peningkatan pendapatan, peningkatan peluang pekerjaan, perubahan mata pencaharian, peningkatan pemamfaatan perumahan sebagai tempat usaha, peningkatan kondisi jalan, dan peningkatan kondisi drainse.
\end{abstract}

\begin{abstract}
The increasing need for housing and limited land in urban center shifts housing development to the suburbs. The suburb of Kendari, Baruga District, experienced significant and sporadic housing developments. The development of housing triggers social, economic, and environmental impacts on local communities around housing that had settled before housing developed there. This research aims to describe the process of housing development in the Baruga District, as well as assess the impact of housing development on the community around the housing. The method used in this study uses a mixed method research approach, which is a research that combines qualitative and quantitative approaches. The findings of this study are the development of housing in Baruga Subdistrict from the economic and environmental aspects does not have a positive impact on the community around housing development. But in the social aspects of housing development has a positive impact on the community around housing development. Eleven indicators examined related to the impact of housing development on social, economic and environmental conditions of the community around housing, there are only four indicators that have a positive impact on the community around housing development, which are increasing social activities, improving social relations, improving the quality of social life, increasing the availability of street lights and improving waste services. While the other six indicators did not significantly impact the community around housing development, which are increased income, increased employment opportunities, changes in livelihoods, increased use of housing as a place of business, improved road conditions, and improved drainage conditions.
\end{abstract}

\section{A. LATAR BELAKANG}

Perumahan dan pemukiman merupakan upaya untuk memenuhi salah satu kebutuhan dasar manusia, sekaligus untuk meningkatkan mutu lingkungan kehidupan, memberi arah pada pertumbuhan wilayah, memperluas lapangan kerja serta menggerakkan kegiatan ekonomi dalam rangka peningkatan dan 
pemerataan kesejahteraan masyarakat. Seperti yang di ungkapkan oleh Budihardjo (1987) bahwa pembangunan dan pengembangan kawasan permukiman merupakan prakondisi untuk meningkatkan kesejahteraan masyarakat. Sehubungan dengan hal tersebut, maka upaya pembangunan perumahan dan pemukiman terus menerus ditingkatkan untuk menyediakan perumahan dengan jumlah yang makin meningkat, dengan harga yang terjangkau oleh masyarakat terutama golongan yang berpenghasilan rendah.

Perkembangan kota yang ada di Kota Kendari jika diruntut dari awal bermula dari perkembangan kota lama. Kota lama Kendari berada di sisi utara. Seiring dengan perkembangan kota, perkembangan kota lama Kendari semakin lama semakin pesat hingga menjalar ke kawasan sekitarnya mulai arah perkembangan kota yang paling terlihat adalah perkembangan ke arah selatan kota Kendari. Perkembangan kota Kendari menjalar terus-menerus hingga ke kawasan pinggiran kota Kendari, terutama di Kecamatan Baruga

Semakin pesatnya pertumbuhan suatu kota pada dasarnya akan diiringi dengan kebijakan pengembangan wilayah dari pemerintah kota, salah satunya dalam pembangunan perumahan. Salah satu upaya yang dilakukan pemerintah pusat dalam memenuhi kebutuhan perumahan tertera dalam dalam Undang Undang No 17 Tahun 2007, yakni untuk memenuhi kebutuhan rumah sebanyak 1,2 juta per tahun, dimana arah kebijakan dan strategi terfokus pada upaya untuk meningkatkan akses masyarakat berpenghasilan rendah terhadap hunian yang layak, aman, dan terjangkau serta di dukung oleh penyediaan sarana dan prasarana serta utilitas yang memadai. Kegiatan pembangunan perumahan meliputi beberapa provinsi dan kota, salah satunya Provinsi Sulawesi tenggara di Kota Kendari.

Perkembangan perumahan yang begitu signifikan terjadi saat ini pada Kecamatan Baruga, Kota Kendari, seharusnya dapat memberikan dampak terhadap masyarakat yang sudah tinggal atau bermukim sebelum adanya perumahan, salah satunya dapat memberikan peluang lapangan pekerjaan terhadap masyarakat di sekitar perumahan yakni dengan membuka usaha seperti warung kelontong, rumah makan, café, bengkel, laundri, pembantu rumah tangga dan lain-lain sebagainya yang tujuannya untuk mengakomodasi segala kebutuhan kehidupan masyarakat penghuni perumahan. Seperti yang dikatakan Amelia (2014) bahwa keberadaan perumahan baru di sekitar lingkungan masyarakat akan menimbulkan dampak possitif maupun negatif. Dampak positif dari adanya perumahan yaitu dapat memberi manfaat besar terhadap kondisi kehidupan masyarakat di sekitar perumahan, di mana masyarakat dapat memperluas lapangan kerja dan mempunyai kesempatan usaha serta akan terjadi peningkatan infastruktur seperti jalan dan drainse yang akan ikut terbangun, penerangan jalan yang akan tertata dengan baik, dan peningkatan lainnya seperti jembatan,listrik,air minum,dan lain-lain. Dikatakan oleh Fitriani, dkk (2015) bahwa munculnya perumahan di sekitar lingkungan masyarakat memberikan pengaruh besar terhadap kehidupan ekonomi masyarakat sekitarnya salah satunya dalam penyerapan lapangan pekerjaan dan perubahan pekerjaan bagi penduduk masyarakat di sekitar perumahan, terutama masyarakat yang hanya bekerja sebagai buruh lepas dan pengangguran, sehingga adanya perumahan menyebabkan masyarakat dapat memperoleh pekerjaan. Selain itu, munculnya perumahan mempengaruhi perubahan mata pencaharian masyarakat sekitar perumahan, sebelum adanya perumahan masyarakat bekerja di bidang tertentu yang penghasilannya belum tentu mencukupi untuk kehidupan sehari-hari seperti buruh lepas dan ada juga masyarakat yang belum mempunyai pekerjaan, sehingga keberadaan perumahan, masyarakat akan beralih ke pekerjaan lain dengan melihat potensi ekonomi dari adanya pembangunan perumahan di sekitar lingkungan masyarakat.

Berdasarkan rangkaian uraian dari penjelasan diatas, peneliti akhirnya tertarik untuk meneliti dampak dari adanya pembangunan atau perkembangan perumahan khususnya yang terjadi pada Kecamatan Baruga, Kota Kendari. Hal tersebut dikarenakan, peneliti menduga bahwa dampak positif yang selalu dihasilkan oleh adanya pembangunan perumahan, khususnya pada peningkatan ekonomi dan lingkungan (infastruktur) masyarakat, tidak terjadi pada masyarakat di sekitar perumahan Kecamatan Baruga, Kota Kendari. Kemudian berdasarkan hasil observasi awal yang telah dilakukan di sekitar perumahan Kecamatan Baruga, menunjukan bahwa kondisi infastruktur khususnya jalan dan drainase serta ketersediaan lampu jalan atau penerangan di sekitar perumahan terbilang masih sangat buruk. Bahkan beberapa tempat di temukan, khususnya di sekitar perumahan di Kelurahan Watubangga dan Kelurahan Baruga masih belum terdapat drainase. Buruknya infasturuktur di Kecamatan Baruga sering kali di muat di media massa, yang menyebutkan bahwa infastruktur khususnya jalan dan drainase di Kecamatan Baruga sudah mencapai tingkat kronis buruknya. Bahkan buruknya infasturuktur mengindikasikan penyebab masalah banjir yang sering dialami masyarakat pada Kecamatan Baruga, terlebih masyarakat yang tinggal di Kelurahan Wundudopi dan Lepo-Lepo.

\section{B. METODE PENELITIAN}

Metode Penelitian merupakan proses mendapatkan dan mengolah data untuk tujuan tertentu dengan cara yang rasional, empirik, dan sistematis (Sugiyono, 2013). Dalam metode penelitian ini akan dilakukan pembahasan meliputi pendekatan penelitian,alat/instrument penelitian, teknik 
pengumpulan data,populasi dan sampel,variable dan indikator serta teknik analisis yang digunakan.

Metode yang digunakan dalam penelitian ini menggunakan pendekatan penelitian campuran (mix method) yaitu penelitian yang menggambungkan antara pedekatan kualitatif dan kuantitatif. Menurut Sugiyono (2013) penelitian mix method adalah metode penelitian dengan mengkombinasikan antara dua metode penelitian sekaligus, yakni kualitatif dan kuantitatif dalam suatu kegiatan penelitian, sehingga akan diperoleh data yang lebih komprehensif, valid, reliabel, dan objektif. Metode ini digunakan untuk memberdalam pembahasan penelitian sehingga akan didapatkan hasil yang lebih akurat yang berkaitan dengan dampak perkembangan perumahan terhadap kondisi masyarakat disekitar perumahan.

Pengumpulan data primer dilakukan dengan menggunakan tiga teknik pengumpulan data yaitu

\section{Observasi}

Observasi lapangan merupakan teknik pengumpulan data yang bertujuan untuk mendapatkan data primer dengan cara mengamati langsung objek yang diteliti untuk menemukan suatu proses dan kondisi yang terjadi sesuai kenyataan di lapangan. Pada penelitian ini, observasi lapangan yang dilakukan yaitu melihat langsung kondisi fisik Wilayah Kecamatan Baruga mengenai perumahan dan lingkungan sekitarnya, meliputi: jumlah perumahan,lokasi sebaran perumahan dan kegiatan sosial-ekonomi masyarakat disekitar perumahan Kecamatan Baruga.

\section{Wawancara}

Wawancara adalah suatu bentuk komunikasi verbal atau percakapan yang bertujuan memperoleh infromasi dengan mengajukan beberapa pertanyaan kepada narasumber yang terpercaya. Wawancara dilakukan antara dua orang atau lebih.

\section{Kuisioner}

Kuisioner merupakan teknik pengumpulan data dengan menggunakan daftar pertanyaan yang disebarkan untuk diisi dan kemudian dikembalikan kepada peneliti dengan tujuan untuk mendapatkan keterangan dari sumber yang beraneka ragam lokasinya dan tersebar. Pertanyaan-pertanyaan dalam kuesioner ini memungkinkan untuk menggali pendapat masyarakat, dan responden diberi kebebasan untuk menjawab sesuai dengan pendapatnya. Kuisioner digunakan untuk meminta keterangan tentang fakta atau pendapat yang diketahui dari responden. Dalam penelitian ini, populasi dari kuisioner diajukan kepada responden yang terkait dengan objek studi dalam hal ini yaitu masyarakat lokal di sekitar perumahan di Kecamatan Baruga Kota Kendari.

Pengumpulan data sekunder dilakukan dengan menggunakan dua teknik pengumpulan data yaitu

\section{Dokumentasi}

Dokumentasi merupakan pengumpulan dokumen dokumen administratif, artikel, agenda rapat, maupun dokumen - dokumen yang terkait dengan penelitian. Dalam hal ini dokumen - dokumen yang dapat dikumpulkan yaitu terkait dengan dampak perkembangan perumahan terhadap kondisi sosial ekonomi dan lingkungan, yaitu meliputi : data kependudukan untuk melihat perkembangan penduduk Kecamatan Baruga, data kondisi sosial ekonomi untuk melihat jenis-jenis kegiatan ekonomi masyarakat, data penggunaan lahan untuk melihat perkembangan penggunaan lahan Kecamatan Baruga, peta-peta terkait penelitian, dan lain-lain

\section{Rekaman Arsip}

Rekaman arsip merupakan teknik pengumpulan data baik data historis maupun data saat ini. Dalam penelitian ini dapat berupa data statsitik Kecamatan dalam Angka time series. Dokumentasi dan rekaman arsip dapat diperoleh di beberapa instansi maupun pihak swasta yang terkait dengan penelitian ini.

Gambaran pekembangan perumahan dalam setiap periode waktu 10 tahun yaitu pada tahun 1980-2018, hal tersebut dilakukan karena melihat awal mula pembangunan perumahan hingga saat ini selalu cenderung meningkat, terlebih dalam periode waktu 10 tahun terakhir yakni pada tahun 2011-2018. Berdasarkan hal tersebut didapatkan tiga periode pembangunan perumahan yang terjadi pada Kecamatan Baruga yaitu periode pertama tahun 1980-1990, periode kedua tahun 1991-2000 dan periode ketiga tahun 20102018. Adapun variable yang dipilih dalam perkembangan perumahan setiap periode waktu 10 tahun meliputi: 1) jumlah perumahan, 2) pola/sebaran perumahan, 3) kelas perumahan menengah bawah, menengah dan menegah atas, 4) pelaku atau penyelenggara pembangunan perumahan yang meliputi pengembang perumahan yang dilakukan oleh pengembangan swasta dan pemerintah, 5) jenis perumahan baru dan perumahan lama. Variable jenis perumahan baru dan lama digunakan untuk mengetahui apakah ada perbedaan dampak yang dihasilkan terhadap masyarakat yang tinggal disekitar perumahan baru dan masyarakat yang tinggal di perumahan lama. Perkembangan perumahan baru yang dimaksud meliputi perumahan yang berkembang pada periode pertama dan kedua yaitu tahun 1980 sampai 2009, sedangkan perumahan baru yaitu perumahan yang berkembangan pada periode ketiga yaitu tahun 20102018. Variable tersebut dipilih sendiri oleh peneliti melihat bahwa perkembangan perumahan yang terjadi pada periode 1980-2010 seharusnya masyarakat sudah mendapatkan dampak dari adanya perumahan.

\section{HASIL DAN PEMBAHASAN}

Kebijakan pengembangan

Kawasan permukiman pada Kecamatan Baruga tidak lepas dari dari meningkatnya kebutuhan lahan tempat tinggal bagi masyarakat, apalagi kawasan 
Kecamatan Baruga masih memiliki banyak lahan kosong. Sebelum terjadi perkembangan permukiman/perumahan pada Kecamatan Baruga, yakni pada tahun 1980, arah perkembangan permukiman di Kota Kendari terpusat pada kawasan Kota Lama yakni di Wilayah Kecamatan Kecamatan Kendari, Kecamatan Kendari Barat, Kecamatan Puwatu, dan Kecamatan Mandonga atau terpusat pada Wilayah Utara Kota Kendari. Kemudian pada tahun 1990 perkembangan mulai menjalar sedikit kearah selatan Kota Kendari, yakni di Wilayah Kecamatan Kadia dan Kecamatan WuaWua. Tahun 2000 dan 2010 arah perkembangan permukiman mulai menunjukan kearah pinggiran Kota Kendari salah satunya terjadi pada Kecamatan Baruga, hingga pada tahun 2018 perkembangan permukiman di Kecamatan Baruga sudah berkembang pesat.

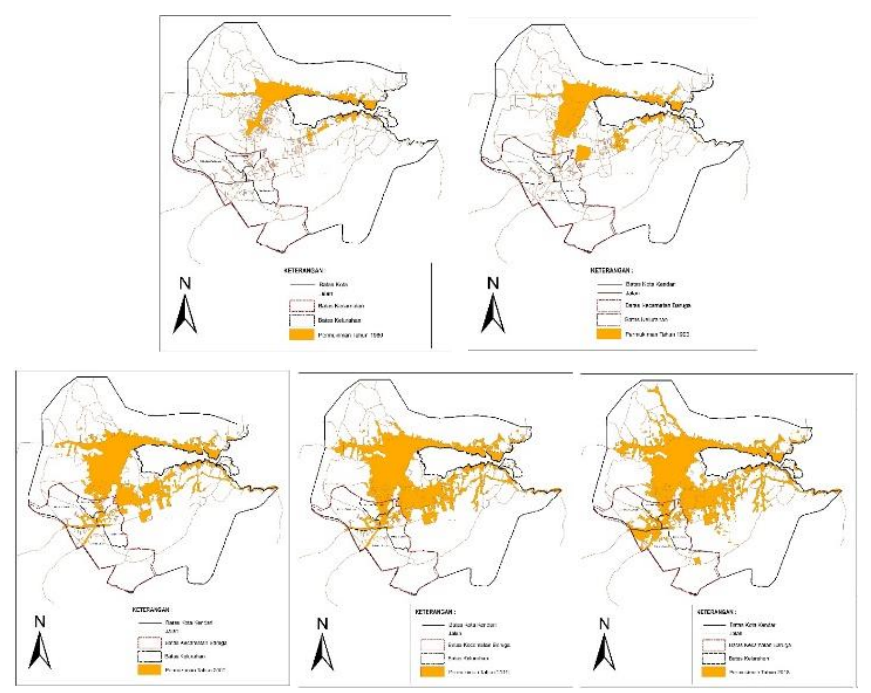

Gambar 1 : Perkembangan permukiman Kota Kendari tahun 1980-2018

Berdasarkan gambar di atas, dapat dilihat bahwa perbedaan utama dari tahun 1980 hingga tahun 2018 adalah terjadi perluasaan area ruang yang digunakan untuk area permukiman. Yang paling terlihat pada gambar di atas adalah arah perluasan area permukiman mengarah ke wilayah Kecamatan Baruga di sebelah barat daya Kota Kendari. Atau dengan kata lain karakteristik perkembangan permukiman pada Kota Kendari cenderung ke arah selatan atau hingga kearah kawasan pinggiran Kota Kendari yakni pada Kecamatan Baruga. Perkembangan permukiman juga menunjukan arah perkembangan yang mengikuti jalur transportasi jalan.

Kecamatan Baruga merupakan wilayah Kecamatan terluas dari 11 Kecamatan yang ada di Kota Kendari. Hal tersebut memberikan potensi pada beberapa sektor terutama dalam hal pengembangan perumahan. Selain itu letak geografis Kecamatan Baruga yang cukup menjanjikan dalam hal pertumbuhan kawasan perumahan, karena wilayah Kecamatan Baruga berada pada posisi berbatasan dengan Kecamatan Kambu yang merupakan pusat Kawasan Pemerintahan di Kota Kendari,dan Kecamatan Wua-wua yang merupakan Kawasan Pusat Ekonomi Perdagangan dan Jasa, serta dekat dengan akses menuju Bandara Udara Haluoleo, yang berada di wilayah kabupaten Konawe Selatan di mana wilayahnya berbatasan langsung dengan wilayah Kecamatan Baruga. Hal tersebut menjadikan Kecamatan Baruga sebagai daerah menjanjikan dan memiliki potensi besar untuk pembangunan perumahan.

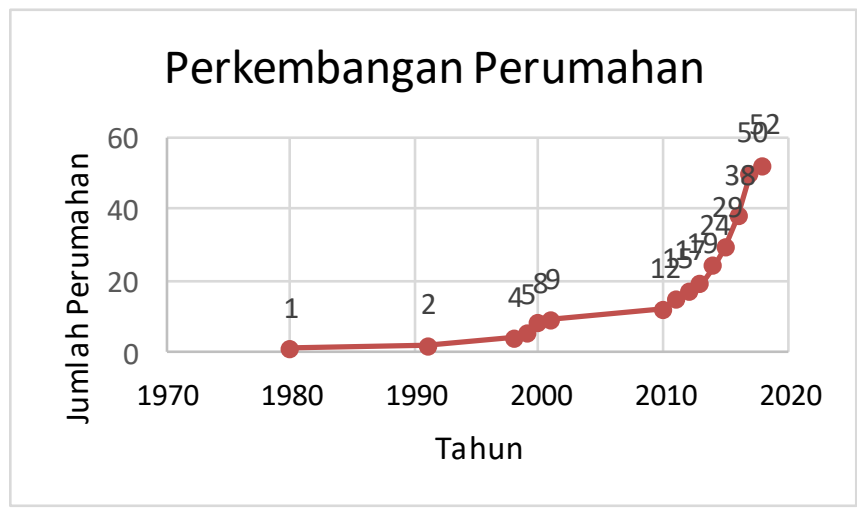

Gambar 2 : Grafik Perkembangan Perumahan Kecamatan Baruga

Sehubungan dengan hal tersebut melihat telah terjadi perkembangan perumahan pada Kecamatan Baruga, oleh karena itu, pada analisis ini, peneliti akan membahas sekaligus menggambarkan seperti apa perkembangan perumahan yang terjadi di Kecamatan Baruga, Kota Kendari. Analisis perkembangan perumahan diawali dengan menganalisis jumlah perumahan dan pola sebaran perumahan serta pelaku pembangunan dan jenis perumahan yang berkembang. Selanjutnya, di lakukan juga indentifikasi perkembangan penggunaan lahan secara umum meliputi perkembangan kegiatan ekonomi, sarana dan prasarana yang berkembang disekitar lingkungan perumahan masyarakat. Dan terakhir, akan di lakukan juga analisis mengenai respon masyarakat lokal dalam menanggapi perkembangan perumahan yang terjadi disekitar lingkungan masyarakat, hal ini dilakukan untuk mengetahui apakah respon masyarakat, sesuai dengan dampak yang di rasakan nantinya.

\section{Identifikasi Perkembangan Perumahan Berdasarkan Periode Tahun 1980-2018}

Identifikasi perkembangan perumahan berdasarkan periode tahun, ini dilakukan peniliti dalam rangka untuk mempermudah analisis gambaran perkembangan perumahan yang terjadi pada Kecamatan Baruga, Kota Kendari. Perkembangan perumahan berdasarkan periode tersebut di identifikasi berdasarkan setiap awal mula pembangunan perumahan. Dari hasil indentifikasi 
perkembangan perumahan berdasarkan periode tahun di dapatkan perkembangan perumahan yang terjadi terbagi menjadi tiga periode waktu setiap 10 tahun.

Pada awalnya, sebelum terjadinya pembangunan perumahan, sebagian besar tata guna lahan di Kecamatan Baruga merupakan kawasan hutan. Awal mula atau pada periode pertama pembangunan perumahan di Kecamatan Baruga, dimulai pada tahun 1980. Pada tahun 1980 tersebut diketahui hanya terdapat satu perumahan yang bertahan hingga sampai tahun 1990. Kemudian pada periode kedua pembangunan perumahan di Kecamatan Baruga dimulai lagi pada tahun 1991 atau berselang waktu 10 tahun sejak pembangunan perumahan pada periode pertama. Pembangunan perumahan yang terjadi pada tahun 1991 tersebut berjalan hingga sampai tahun 2001 yakni: tahun 1991,1998,1999,2000 dan 2001. Setelah tahun 2001 diketahui tidak ada lagi pembangunan perumahan yang terjadi pada Kecamatan Baruga, dan hal tersebut bertahan hingga sampai tahun 2009. Selanjutnya pada periode ketiga, pembangunan perumahan di mulai lagi pada tahun 2010 atau berselang 9 tahun sejak pembangunan terakhir perumahan pada periode kedua yaitu tahun 2001. Pembangunan perumahan pada periode ketiga ini, bisa dibilang awal mula perkembangan perumahan yang terjadi pada Kecamatan Baruga, di mana pada periode tersebut berlangsung pembangunan perumahan setiap tahunnya hingga sampai saat ini.

Untuk melihat lebih jelas gambaran perkembangan perumahan meliputi jumlah perumahan,pola sebaran perumahan dan pelaku pembangunan perumahan berdasarkan periode pada Kecamatan Baruga yang sudah dijelaskan sebelumnya, dapat dilihat pada penjelasan subbab berikut ini

\section{Jumlah dan Pola Sebaran Perumahan Serta Pelaku Pembangunan Pada Periode Pertama, Tahun 1980-1990 Kecamatan Baruga}

Seperti yang sudah dijelaskan pada bab sebelumnya, mengenai identifikasi perkembangan perumahan, diketahui bahwa awal mula atau pada periode pertama pembangunan perumahan pada Kecamatan Baruga, Kota Kendari dimulai pada tahun 1980. Dalam kurun waktu tahun 1980 sampai dengan tahun 1990 pembangunan perumahan di Kecamatan Baruga, hanya terdapat satu perumahan. Di mana dari hasil survey, diketahui perumahan tersebut adalah perumahan findayani yang terletak di jalan DI Panjaitan kelurahan wundudopi.

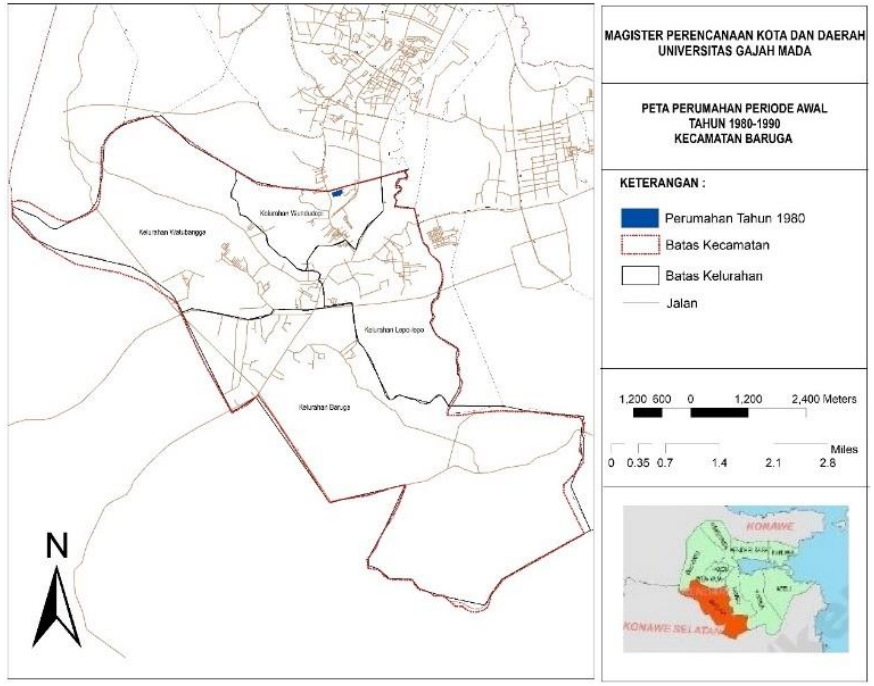

Gambar 3 : Peta Perumahan Periode Awal Tahun 1980-1990

Berdasarkan gambar di atas, diketahui bahwa pada periode pertama tahun 1980 sampai dengan 1990 hanya terdapat satu perumahan yaitu perumahan findayani yang berlokasi di jalan DI Panjaitan kelurahan wundudopi, Kecamatan Baruga. Perumahan findayani memiliki jumlah rumah sebanyak 85 unit dengan luas kawasan perumahan sebesar 22757m2. Perumahan findayani berada dekat dengan perbatasan Kecamatan Wua-wua atau pusat kota Kendari. Dengan gambaran lokasi perumahan diatas menunjukan bahwa proses perkembangan awal pembangunan perumahan pada Kecamatan Baruga menunjukan dimulai dari pusat kota atau dari arah utara Kecamatan Baruga, Kota Kedari.

Selanjutnya berdasarkan hasil survey primer didapatkan bahwa pelaku dalam pembangunan perumahan yang dilakukan pada periode tersebut merupakan pembangunan yang dilakukan oleh developer swasta dengan jenis perumahan subsidi atau kelas menengah kebawah yang di peruntukan untuk kalangan masyarakat berpenghasilan rendah.

\section{Jumlah dan Pola Sebaran Perumahan Serta Pelaku Pembangunan Pada Periode Kedua, Tahun 1991-2001 Kecamatan Baruga}

Setelah periode pertama pembangunan perumahan yaitu pada tahun 1980, tidak ada lagi pembangunan perumahan yang terjadi pada Kecamatan Baruga hingga sampai tahun 1990. Selanjutnya pembangunan perumahan pada Kecamatan Baruga dimulai lagi pada tahun 1991 sampai dengan tahun 2001 atau pada periode kedua. Pada periode kedua menunjukan pada tahun 1991 sampai dengan Tahun tahun 2001 terdapat 8 perumahan yang tersebar di seluruh kelurahan Kecamatan Baruga. 


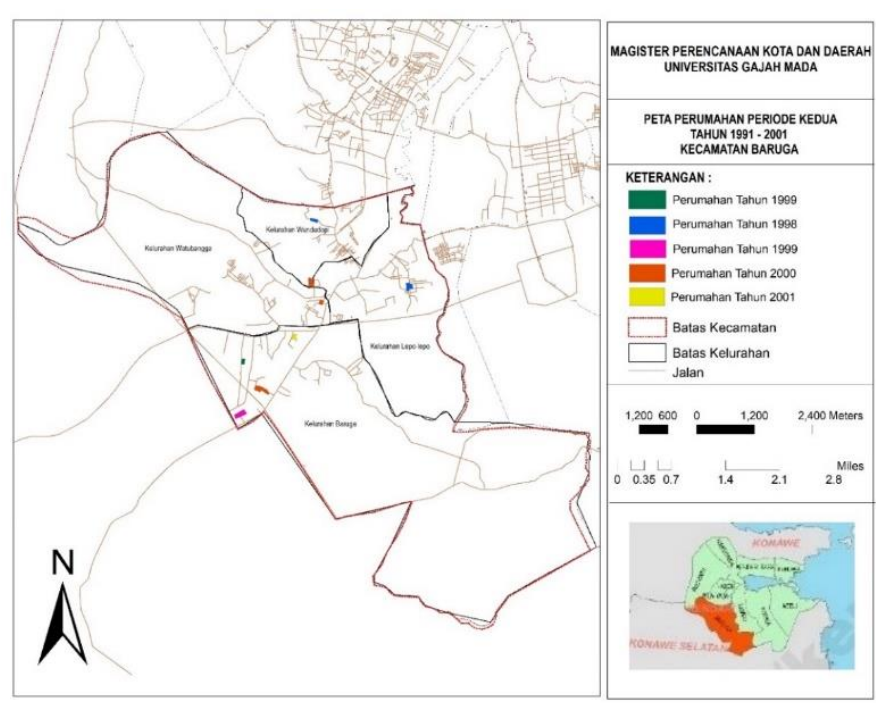

Gambar 4 : Peta Perumahan Periode Kedua Tahun 1991-2001

Berdasarkan tabel dan gambar diatas, dapat dilihat bahwa pada periode tersebut menunjukan terjadi perkembangan perumahan diseluruh kelurahan, antara lain 2 perumahan di Kelurahan Wundudopi, 1 perumahan di Kelurahan Lepo-lepo, 1 perumahan di Kelurahan Watubangga dan 4 perumahan di Kelurahan Baruga. Sedangkan berdasarkan tahun, pembangunan perumahan pada periode tersebut hanya terjadi pada tahun 1991,1998,1999,2000 dan 2001. Selain itu, jumlah unit rumah yang terbangun pada periode tersebut berjumlah sebanyak 1060 unit rumah dengan total luas lahan seluruh perumahan sebesar 13 ha.

Sebaran pola perumahan yang terjadi pada periode tersebut menunjukan pola perkembangan yang terlihat menyebar dan terjadi pergeseran perkembangan hingga kawasan pinggiran Kota Kendari atau berbatasan langsung dengan Wilayah Kabupaten Konawe Selatan.

Selanjutnya Pada periode tersebut dari hasil survey primer, menunjukan bahwa pelaku pembangunan perumahan mayoritas di promotori oleh pengembang swasta dan hanya terdapat satu perumahan yang dibangun oleh pemerintah yakni perumahan kehutanan. Sedangkan untuk tipe dan jenis perkembangan perumahan seluruhnya merupakan perumahan tipe subsidi dan perumahan kelas menegah kebawah.

\section{Jumlah dan Pola Sebaran Perumahan Serta Pelaku Pembangunan Pada Periode Ketiga, Tahun 2010 - 2018 Kecamatan Baruga}

Setelah pada periode kedua yaitu pada tahun 19912001, berdasarkan hasil indentifikasi dari hasil survey primer yang telah dilakukan, diketahui bahwa tidak ada lagi pembangunan perumahan pada tahun 2002 hingga tahun 2009. Awal mula Pembangunan perumahan atau pada periode ketiga kembali dimulai pada tahun 2010 sampai dengan tahun 2018. Berdasarkan hasil survey primer, didapatkan bahwa pada periode ketiga terjadi perkembangan perumahan yang signifikan dari periodeperiode sebelumnya, di mana pada periode ketiga ini, didapatkan perkembangan perumahan yang terjadi sebanyak 43 perumahan dan tersebar di seluruh kelurahan di Kecamatan Baruga.

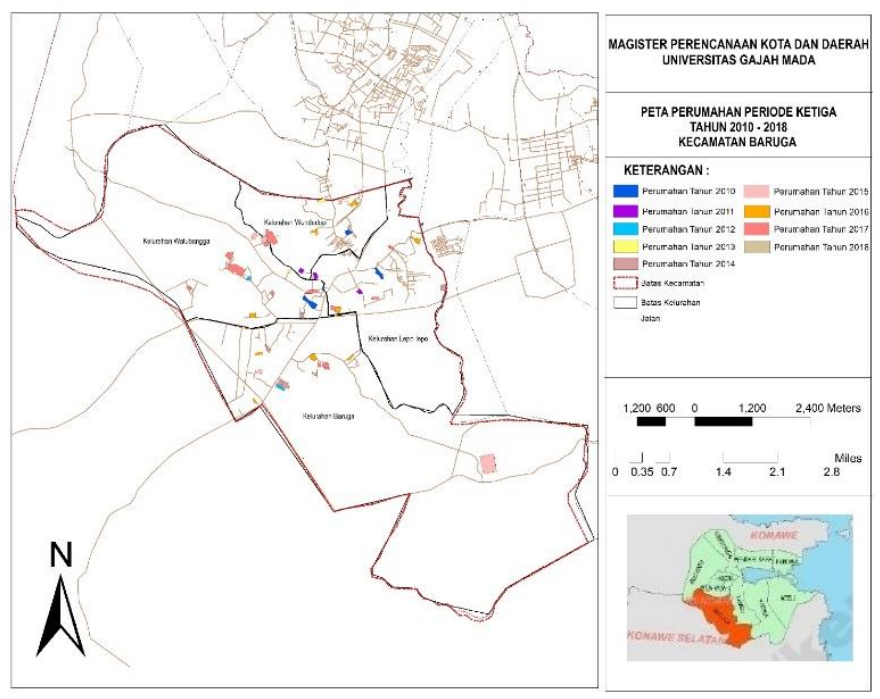

Gambar 5 : Peta Perumahan Periode Ketiga Tahun 2010-2018

Berdasarkan tabel dan gambar diatas, dapat dilihat bahwa perkembangan perumahan pada periode ketiga, yaitu awal dari pembangunan perumahan pada periode ketiga yang dimulai pada tahun 2010, menunjukan perkembangan yang signifikan dari periode-periode sebelumnya setiap tahunnya, di mana setelah periode kedua yaitu tahun 1991-2001 menujukan tidak ada pembangunan perumahan pada tahun 2002 hingga 2009 di Kecamatan Baruga Kota Kendari.

Perkembangan perumahan pada periode ketiga, bisa dilihat juga bahwa perkembangan perumahan yang terjadi berbeda dengan periode-periode sebelumnya. Perkembangan perumahan pada periode ketiga menujukan selalu ada pembangunan perumahan setiap tahunnya. Di mana pada tahun 2010 atau awal dari pembangunan perumahan pada periode ketiga terdapat 3 pembangunan perumahan, tahun 2011 terdapat 3 pembangunan perumahan, tahun 2012 terdapat 2 pembangunan perumahan, tahun 2013 terdapat 2 pembangunan perumahan, kemudian tahun 2015 mengalami peningkatan pembangunan perumahan menjadi 5 pembangunan perumahan, 2016 terdapat 9 pembangunan perumahan, selanjutnya tahun 2017 terdapat 12 pembangunan perumahan dan pada tahun 2018 terdapat 2 pembangunan perumahan.

Pembangunan perumahan pada periode ketiga secara keseluruhan memiliki jumlah sebanyak 43 pembangunan perumahan yang tersebar di seluruh kelurahan. Pembangunan perumahan berdasarkan kelurahan pada periode ketiga terlihat bahwa paling banyak terjadi pada kelurahan baruga yaitu sebanyak 13 perumahan, sedangkan yang paling kecil terdapat di kelurahan wundudopi yaitu sebanyak 7 perumahan. 
Pola perkembangan perumahan pada periode ketiga menunjukan pola yang beragam ada yang terlihat mengelompok dan ada yang terlihat menyebar/meloncat. Namun secara umum perkembangan perumahan pada periode ketiga Kecamatan Baruga cenderung menyebar.

Selanjutnya, berdasarkan pelaku, tipe dan jenis perkembangan perumahan pada periode ketiga, terlihat pelaku pembangunan perumahan masih cenderung dilakukan oleh pihak pengembang swasta. Sedangkan untuk jenis dan tipe perumahan yang berkembangan pada periode ketiga terlihat bervariasi ada perumahan yang subsidi dan non subsidi, dan ada juga perumahan kelas menegah bawah, menengah dan menegah atas, namun perkembangan perumahan cendering lebih banyak perumahan subsidi dan perumahan kelas menegah bawah.

Berdasarkan tabel diatas, dapat dilihat bahwa pelaku, tipe dan jenis perumahan yang berkembangan pada periode ketiga yaitu tahun 2010-2018, menunjukan untuk pelaku pembangunan perumahan cenderung dilakukan oleh pengembang swasta, hanya terdapat 1 perumahan yang di bangun oleh pemerintah yaitu perumahan BTN PNS Kota Kendari. Sedangkan untuk tipe dan kelas perumahan, rata-rata perumahan yang dibangun merupakan perumahan subsidi dari pemerintah dan kelas perumahan menegah bawah. Hanya terdapat 6 perumahan non subsidi yaitu perumahan baruga nusantara, green baruga, the villas, puri saranani, dan permata koila residence. Untuk kelas perumahan hanya terdapat 1 perumahan kelas menegah atas yaitu perumahan the villas, dan kelas perumahan menegah terdapat 5 yaitu baruga nusantara, green baruga, puri saranani, dan permata koila residence. Sedangkan sisanya seluruh perumahan merupakan perumahan kelas menegah bawah

\section{Implikasi Perkembangan Kecamatan Baruga}

Dari hasil observasi lapangan serta pengamatan pada potret perkembangan perumahan di wilayah Kecamatan Baruga memperlihatkan kondisi perumahan dengan berbagai tipe rumah bervariasi, mulai dari tipe 21 hingga tipe 54. Namun secara umum memang ratarata kondisi perumahan yang berkembangan merupakan perumahan kelas menengah hingga menengah ke bawah.

Selain itu, kondisi perumahan yang berkembang juga memperlihatkan dua karakteristik tipe perumahan, ada perumahan yang di batasi oleh pagar pembatas dan ada juga perumahan tidak di batasi oleh pagar pembatas namun hanya di tandai dengan gapura. Dari hasil pengamatan, perumahan yang tidak di batasi oleh pagar pembatas lebih dominan berkembang pada Kecamatan Baruga. Selain itu dari hasil pengamatan, biasanya perumahan yang tidak di batasi dengan pagar pembatas biasanya hidup berdampingan dengan masyarakat lokal di sekitarnya. Oleh karenanya kebanyakan masyarakat penghuni perumahan memiliki hubungan yang baik dengan masyarakat di sekitar perumahan. Beberapa gambaran kondisi perumahan pada Kecamatan Baruga dapat dilihat pada gambar berikut ini :

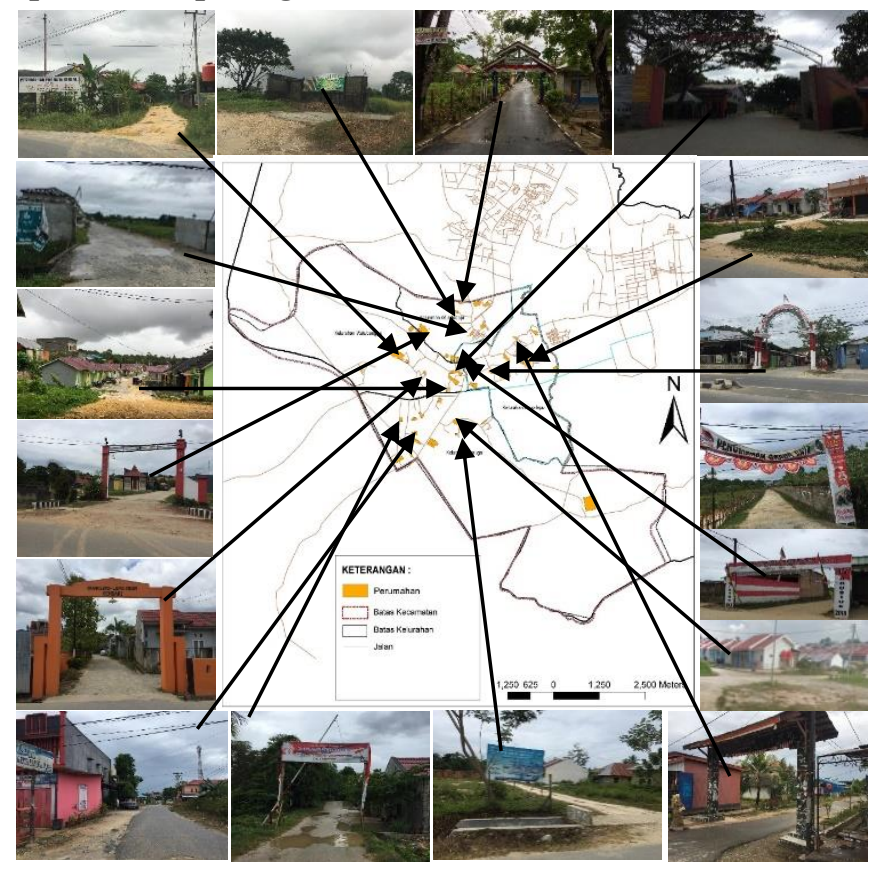

Gambar 6 : Kondisi Perumahan di Kecamatan Baruga

Dari hasil observasi juga peneliti melihat bahwa rata-rata pembangunan perumahan yang terbangun tidak mengikuti konsep pembangunan perumahan yang baik secara umum, pengembang yang membangun perumahan rata-rata tidak mengutamakan pelayanan penyediaan prasarana yang baik serta penyediaan fasilitas umum, mereka hanya melihat peluang bisnis (benefit) akibat tingginya permintaan akan rumah tinggal. Hal tersebut dibuktikan dari hasil observasi beberapa perumahan yang berkembang prasarana pendukung yakni kondisi jalan dan drainase masih tergolong sangat buruk di dalam kawasan perumahan.

Perkembangan perumahan yang terjadi di Kecamatan Baruga dari periode awal hingga saat ini tercapai kondisi lingkungan di sekitar perumahan sebagai berikut :

- Sifat yang selalu ingin berkumpul atau berkelompok pada masyarakat memungkinkan terjadinya suatu lingkungan permukiman yang dipengaruhi oleh kebutuhan atau kepentingan yang sama. Sifat solidaritas yang cukup tinggi di lingkungan masyarakat Kecamatan Baruga merupakan karakter budaya yang telah turun temurun sehingga bisa menerima siapa saja yang datang baik dari wilayah lain di Provinsi Sulawesi Tenggara maupun pendatang yang berasal dari luar Provinsi. Biasanya para pendatang yang mencari kerja dan telah lama tinggal atau telah menetap tidak membentuk lingkungan tersendiri, mereka berbaur dalam lingkungan permukiman dengan masyarakat lokal. Selain itu, sejak terjadi perkembangan 
perumahan, masyarakat penghuni perumahan dan masyarakat di sekitar perumahan hidup rukun berdampingan dan tidak pernah terjadi konflik.

- Perkembangan perumahan yang terjadi pada Kecamatan Baruga, memberi andil besar pada masyarakat di sekitar perumahan dalam memanfaatkan berbagai peluang ekonomi yang ada. Hal tersebut dibuktikan dari hasil survey menunjukan banyak kegiatan-kegiatan usaha bermunculan yang dibuat oleh masyarakat yang tinggal di sekitar lingkungan perumahan. Kegiatan usaha tersebut meliputi usaha warung kelontong, usaha counter pulsa, salon kecantikan, barber shop, bengkel motor, warung makan, dan jasa laundry. Namun dari hasil observasi kegiatan usaha yang mendominasi yaitu kegiatan usaha warung kelontong dan counter pulsa.

- Dari hasil survey, berkembangnya perumahan di Kecamatan Baruga sebenarnya telah diimbangi dengan peningkatan sarana pendukung kehidupan masyarakat Kecamatan Baruga khusunya sarana Pendidikan dan kesehatan. Namun kondisi prasarana khususnya jalan dan drainase masih ditemukan di beberapa tempat dengan kondisi kondisi tergolong buruk. Di mana dari hasil obeservasi ditemukan masih terdapat jalan yang rusak di beberapa tempat. Hal tersebut tentunya akan merugikan masyarakat dalam melakukan aktivitas seharihari. Selain itu ditemukan juga banyak rumahrumah kondisi drainase yang tidak berfungsi dengan baik. Bahkan di beberapa tempat masih sering ditemukan rumah-rumah yang belum mempunyai saluran drainase. Untuk lebih jelasnya dapat dilihat beberapa gambaran kondisi lingkungan di sekitar perumahan Kecamatan Baruga berikut ini :

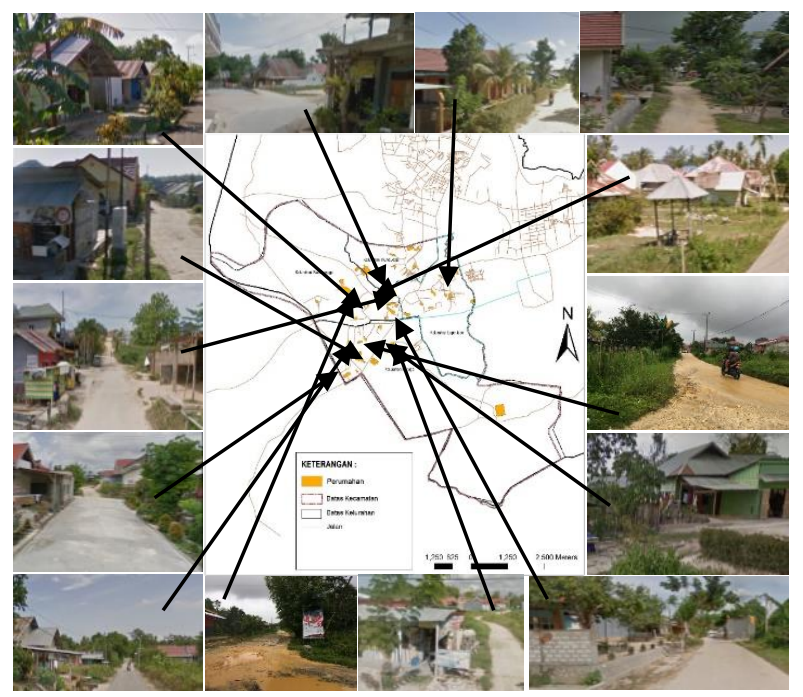

Gambar 7 . Kondisi di sekitar Perumahan di Kecamatan Baruga
Berdasarkan hasil survey yang dilakukan dengan menggunakan kuesioner serta di konfirmasi dengan hasil wawancara, didapatkan mayoritas responden menanggapi dengan positif adanya pembangunan/perkembangan perumahan dilingkungkan sekitar mereka. Hal tersebut dikarenakan, dengan adanya perumahan menurut masyarakat, selain karena faktor ekonomi yakni dengan terbukanya lapangan pekerjaan dan meningkatkan pendapatan khususnya masyarakat yang sudah membuka usaha sebelum adanya perumahan, di sisi lain masyarakat menganggap bahwa pembangunan perumahan akan membuat lingkungan masyarakat menjadi lebih ramai dan lebih aman. Untuk lebih jelasnya dapat dilihat pada table respon masyarakat terhadap perkembangan perumahan pada Kecamatan Baruga.

Tabel 1. Persepsi masyarakat mengenai pembangunan perumahan

\begin{tabular}{llcc}
\hline \multicolumn{1}{c}{ Keterangan } & \multicolumn{1}{c}{ Persepsi Masyarakat } & $\begin{array}{c}\text { Jumlah } \\
\text { responden }\end{array}$ & $\%$ \\
\hline Respon & Peluang Usaha & 108 & 90 \\
\cline { 2 - 4 } & Peningkatan pendapatan & 12 & 10 \\
\cline { 2 - 4 } & Lainnya & - & - \\
\hline \multirow{2}{*}{ Respon Sosial } & Peningkatan Fasilitas & - & - \\
& Pendidikan & - & - \\
\cline { 2 - 4 } & Peningkatan Fasilitas & & - \\
\cline { 2 - 4 } & Kesehatan & - & 100 \\
\cline { 2 - 4 } & Gaya hidup & 120 & \\
\cline { 2 - 4 } Sualitas Hidup & & - \\
& & &
\end{tabular}

\section{TEMUAN/ DISKUSI}

Secara umum perkembangan perumahan di Kecamatan Baruga menunjukan adanya pergeseran secara sporadis hingga ke kawasan pinggiran Kota Kendari dengan pola perkembangan perumahan yang terlihat meloncat. Selain itu perkembangan perumahan yang terjadi diketahui mengalih fungsikan lahan sebesar 147,7 ha dalam kurun waktu tahun 1980 hingga tahun 2018. Namun alihfungsi lahan tersebut diketahui sudah sesuai dengan arahan kebijakan pemerintah yang diatur dalam RTRW. Perkembangan perumahan di Kecamatan Baruga memperlihatkan perkembangan yang signifikan terjadi pada periode ketiga yaitu pada tahun 2010-2018. Pada periode tersebut pembangunan perumahan terjadi setiap tahunnya dan dalam kurun waktu tersebut juga terdapat sebanyak 43 perumahan yang tersebar di seluruh kelurahan. Dibandingkan dengan periode pertama yaitu tahun 1980-1990 hanya terdapat 1 perumahan yang dibangun pada tahun 1980 dan 8 perumahan pada periode kedua yaitu tahun 1991-2001 yang dibangun pada tahun 1991,1998,1999,2000 dan 2001. Perkembangan perumahan yang signifikan pada periode ketiga tidak lepas dari meingkatkatnya jumlah penduduk di Kecamatan Baruga pada tahun 2010 sebesar 43,7 persen dan terus berkembang setiap tahunnya sehingga hal tersebut sekaligus juga meningkatkan kebutuhan akan tempat tinggal bagi masyarakat. 
Perkembangan perumahan yang terjadi pada Kecamatan Baruga juga memicu terjadinya perkembangan kegiatan di wilayah Kecamatan Baruga. Hal tersebut ditandai dengan berkembangannya fasilitas-fasilitas strategis, perdagangan dan jasa, serta perbaikan dan peningkatan infasturktur di Kecamatan Baruga. Dari hasil temuan analisis, menunjukan beberapa fasilitas yang terbangun pasca perkembangan perumahan antara lain: pembangunan Terminal Tipe A pada tahun 2015 yang terletak dikelurahan baruga, pembangunan fasilitas kesehatan yaitu Rumah Sakit Umum Provinsi Sulawesi Tenggara pada tahun 2012 yang terletak di kelurahan watubangga, Rumah Sakit Umum Dwi Sartika pada tahun 2013 yang terletak di kelurahan baruga dan Rumah Sakit Hati Mulya pada tahun 2016 yang terletak di kelurahan wundudopi. Sedangkan pembangunan fasilitas pendidikan yaitu Kampus/Perguruan Tinggi Institute Agama Islam Kendari (IAIN) pada tahun 2014 yang terletak di kelurahan baruga, Universitas Nahdatul Ulama Sulawesi Tenggara (UNUSRA) pada tahun 2015 yang terletak di kelurahan baruga. Kemudian berkembangnya Kawasan Perdagangan dan Jasa di sepanjang jalan arteri yaitu di jalan D.I Panjaitan, Jalan Poros Bandara Haluoleo dan Jalan Brigjen Katamso. Beberapa kegiatan ekonomi tersebut didominasi oleh kegiatan usaha warung makan, kios/warung kelontong dan konter pulsa. Sedangkan dari infastruktur, seperti kondisi jalan dan drainse, walaupun memperlihatkan peningkatan maupun perbaikan khususnya di sepanjang jalan arteri dan kolektor, namun masih banyak juga terdapat jalan-jalan dan kondisi drainse yang masih tergolong buruk terutama di jalan lokal/lingkungan sekitar perumahan masyarakat.

Perkembangan perumahan yang terjadi di Kecamatan Baruga direspon positif oleh masyarakat di sekitar perumahan karena di anggap akan mendatangkan peluang ekonomi dan dapat meningkatkan kualitas hidup sosial dalam hal kenyamanan dan keamanan. Namun fakta dilapangan menunjukan bahwa respon positif tersebut tidak sesuai dengan apa yang dirasakan masyarakat saat ini. Hasil temuan di lapangan menunjukan bahwa perkembangan perumahan yang terjadi, tidak mendatangkan peningkatan ekonomi yang lebih baik terhadap masyarakat disekitar perumahan Kecamatan Baruga. Rata-rata penghuni perumahan di Kecamatan Baruga ikut juga memanfaatkan peluang usaha dari adanya perumahan, seperti membuka usaha warung kelontong, laundry, warung makan dan konter pulsa. Sehingga hal tersebut tidak hanya berdampak terhadap tidak meningkatnya pendapatan masyarakat di sekitar perumahan yang sebelumnya sudah membuat usaha, namun juga berdampak terhadap tidak adanya peluang pekerjaan/usaha bagi masyarakat disekitar perumahan. Kemudian perkembangan perumahan juga tidak berdampak signifikan lebih baik terhadap peningkatan lingkungan (infastukrtur) di sekitar perumahan. Di mana hanya terdapat dua peningkatan yang signifikan lebih baik dirasakan oleh masyarakat di sekitar perumahan, yakni peningkatan pelayanan persampahan dan peningkatan prasarana lampu jalan. Sedangkan infasturktur jalan dan drainse menunjukan peningkatannya tidak cukup signifikan lebih baik. Akan tetapi di sisi lain keberadaan perumahan disekitar lingkungan masyarakat memberikan dampak positif terhadap masyarakat dari aspek sosial. Setelah adanya perumahan kegiatan sosial di lingkungan masyarakat menjadi meningkat. Masyarakat penghuni perumahan juga selalu ikut berpartisipasi dalam kegiatan sosial. Selain itu terjadi juga peningkat kualiats hidup masyarakat di sekitar perumahan. Masyarakat menganggap munculnya perumahan menjadikan lingkungan masyarakat menjadi lebih aman dan ramai. Sedangkan interaksi/ hubungan sosial masyarakat di anggap sama saja, baik sebelum maupun sesudah adanya perumahan.

\section{E. SIMPULAN DAN SARAN}

Perkembangan perumahan yang terjadi pada Kecamatan Baruga, Kota Kendari memberi pengaruh positif terhadap perkembangan Wilayah Kecamatan Baruga. Perkembangan perumahan memicu terjadinya perkembangan fasilitas-fasilitas umum dalam mendukung kehidupan masyarakat seperti fasilitas transportasi, fasilitas pendidikan dan fasilitas kesehatan. Selain itu keberadaan perumahan juga berdampak terhadap perkembangan kegiatan-kegiatan ekonomi perdagangan dan jasa di sepanjang jalan arteri Kecamatan Baruga.

Keberadaan perumahan di sekitar lingkungan masyarakat lokal tidak memberikan dampak/pengaruh yang signifikan lebih baik terhadap masyarakat di sekitar perumahan Kecamatan Baruga. Didapatkan bahwa dari sebelas indikator yang diteliti terkait dampak perkembangan perumahan terhadap kondisi sosial, ekonomi dan lingkungan masyarakat sekitar perumahan. Hanya terdapat empat indikator yang berdampak lebih baik terhadap masyarakat sekitar perumahan, antara lain: peningkatan kegiatan sosial, peningkatan hubungan sosial, peningkatan kualitas hidup sosial, peningkatan ketersediaan lampu jalan dan peningkatan pelayanan persampahan. Sedangkan enam indikator lainnya tidak berdampak signifikan lebih baik terhadap masyarakat sekitar perumahan antara lain: peningkatan pendapatan, peningkatan peluang pekerjaan, perubahan mata pencaharian, peningkatan pemamfaatan perumahan sebagai tempat usaha, peningkatan kondisi jalan, dan peningkatan kondisi drainse.

Perkembangan perumahan yang terjadi pada Kecamatan Baruga seharusnya dapat memberikan dampak positif terhadap masyarakat di sekitarnya. Namun sangat disayangkan perkembangan perumahan 
yang signifikan terjadi tidak memberi banyak dampak positif terhadap masyarakat terutama dalam aspek ekonomi dan lingkungan. Padahal aspek tersebut merupakan aspek penting dalam mempengaruhi kesejahteraan masyarakat di sekitar perumahan. Peningkatan ekonomi yang biasanya paling mendasar yang seharusnya dapat dirasakan oleh masyarakat sekitar perumahan justru hal tersebut tidak dirasakan pada masyarakat di sekitar perumahan Kecamatan Baruga. Salah satu faktor mendasar adalah karena masyarakat penghuni perumahan juga ikut menanfaatkan peluang ekonomi yang ada dengan membuat usaha-usaha di dalam kawasan perumahan. Sama halnya dengan dampak lingkungan, walaupun telah terjadi beberapa peningkatan dalam hal perbaikan infasturktur khususnya jalan dan drainase, namun peningkatan tersebut belum sepenuhnya lebih baik. Karena masih banyak terdapat jalan-jalan rusak ditemukan di beberapa tempat di sekitar perumahan maupun rumah-rumah masyarakat yang kondisi drainasenya tidak berfungsi dengan baik. Bahkan di beberapa tempat juga masih sering ditemukan rumahrumah yang belum mempunyai saluran drainase.

Perkembangan perumahan yang biasanya memberi dampak negatif terhadap masyarakat dari aspek sosial, justru berbeda dengan yang terjadi pada Kecamatan Baruga. Keberadaan perumahan berdampak positif terhadap masyarakat sekitar perumahan, karena tidak hanya meningkatkan kegiatan sosial dan hubungan sosial masyarakat, namun juga dapat meningkatkan kualitas hidup sosial karena masyarakat menganggap bahwa keberadaan perumahan memberi pengaruh terhadap peningkatan kenyamanan dan keamanan dibanding sebelum adanya perumahan. Hal tersebut tidak lepas dari jenis-jenis perumahan yang berkembang di Kecamatan Baruga, di mana rata-rata perumahan yang berkembang merupakan perumahan jenis perumahan kelas menengah ke bawah yang diperuntukan bagi kalangan masyarakat berpengahsilan rendah sehingga tidak ada perbedaan status sosial antara masyarakat penghuni perumahan maupun masyarakat di sekitar perumahan. Apalagi dengan karakteristrik budaya masyarakat lokal yang secara turun temurun selalu menerima dengan baik masyarakat pendatang yang tidak hanya berasal dari wilayah lain di Provinsi Sulawesi Tenggara, namun juga masyarakat pendatang dari luar Wilayah Provinsi Sulawesi Tenggara.

\section{DAFTAR RUJUKAN}

[1] Eko Budiharjo. 2009.Perumahan Permukiman Di Indonesia.Bandung: P.T Alumni

[2] Yunus Hadi Sabari. 2006. Megapolitan (Konsep,Problematika dan Prospek). Yogyakarta : Pustaka pelajar

[3] Kuswartojo, Rosnarti, Effendi, Eko K, Sidi. 2005. Perumahan dan Permukiman di Indonesia. Bandung : Institute Teknologi Bandung

[4] Yunus Hadi Sabari. 2000. Struktur Tata Ruang Kota. Yogyakarta : Pustaka pelajar
[5] Warsono, Agus. Perkembangan Permukiman Pinggiran Kota Pada Koridor Jalan Kaliurang,Kabupaten Sleman. Diakses 21 Februari 2018

[6] Rahman,Arief. 2015. Dampak Pembangunan Perumahan Terhadap Masyarakat setempat. Diakses 3 Januari 2018

[7] Fitriani,Erin, Maliha Elli dan Mirna Nur Alia. 2015. Dampak Pembangunan Perumahan terhadap Kehidupan Sosial Masyarakat. Diakses 3 Januari 2018

[8] Fitria, Isha, Richa Octaviani. 2016. Analisis Dampak Sosial Ekonomi Kebijakan pengembangan Kawasan Mix Use. Diakses 3 Januari 2018

[9] Oktaviani, Afifah Putri. 2012. Dampak adanya Perumahan Johor Baru terhadap Perubahan Kondisi Sosial Ekonomi Rumah Tangga. Diakses 3 Januari 2018

[10] Purnomo, Galuh. 2012. Dampak Sosial Kebijakan Pembangunan Perumahan. Diakses 3 Januari 2018

[11] Indarto, Kukuh Dwi, Sri Rahayu. 2015. Dampak Pembangunan Perumahan Terhadap Kondisi Lingkungan, Sosial Dan Ekonomi Masyarakat Sekitar. Diakses 3 Januari 2018 